\title{
Impact Of Human Resources Accounting On Organizational Performance
}

\author{
Dr. (Mrs.) Asha Sharma \\ Assistant Professor, Department of Commerce, Mahila P. G. Mahavidhalaya, Jai Narain Vyas \\ University, Jodhpur
}

\begin{abstract}
The success of the any organization depends on the quality of its human resources, whether it belong to manufacturing, service or a retail outlet. Physical assets are used to increasing earning capacity of any business organization, likewise human resources are important assets and used to increase productivity, earning capacity, increasing the wealth and profit, market value, economic value added etc. Nowadays because of the global transition service industry has become one of the leading industries which are mainly based on human resources. This study focuses on the current practices in Human Resources Accounting and to measure the impact of HRA on organizational performance. Aim of the study is to make aware about role and contribution of human resources, to measure and valued HRA. Primary data is taken to test the hypothesis. Statistical tools like mean, standard deviation, T-test, F-test, correlation and Likerts five point scales is used to analysis the result.
\end{abstract}

Keywords: Human Resources Accounting, Value Added, Human Resources Management, Efficiency \& productivity, Decision Making

\section{Introduction}

Success of corporate undertakings purely depends upon the quality of human resources. It is accentuated that; Human element is the most important input in any corporate enterprise. The investments directed to raise knowledge; skills and aptitudes of the work force of the organization are the investments in human resource. In this context, it is worthwhile to examine and human resource accounting practices in corporate sector in India and to understand how the HRA is effecting the financial and overall performance of the company.

It is simply an attempt to identifying measuring and communicating information about human resources and it ought to be viewed as a metaphor. It's the way of thinking about management of people. It is a recording of transactions related to the value of human resources.

A popular phenomenon among the Indian corporate world is to disclose information relating to human resource in annual financial statements. In this context, it is necessary to conduct a study to assess the disclosure pattern of HRA information in Indian corporate World.

\section{LITERATURE REVIEW}

Human Resource Accounting information can be useful for managerial decision making in different areas. Many research studies were conducted to prove this. Tomassini (1977) carried out a laboratory study to examine the effects of HRA cost data in personnel layoff decision context. He concluded that HRA cost estimates caused different managerial preferences in the personnel lay off decision context. Gul (1984) attempted to study the usefulness of human resources turnover cost information for labour turnover decisionmaking in a sample of Australian Accounting Firms. Bayes (1984) conducted an empirical investigation of the effects of HRA information on decision-making. Malik (1993) carried out an empirical investigation to know the impact of HRA information on decisionmaking. Sen et.al (2008) in their study make a scientific investigation into whether HR information has any impact on internal decision-making i.e. in the context of personnel management decision-making related to employee recruitment and employee turnover control in banking industry of Bangladesh. There are so many studies that support the hypothesized usefulness of HRA in the process of decision making by internal and external users. There has also been an increasing recognition of the concept of HRA, evidenced by the flow of literature on various aspects of HRA. But there are very few organizations involved in the systematic measurement and reporting of HRA information. Though the users of the information are interested and they welcome HRA reporting but they fail to throw light on this vacuum created by the resistance of the organizations to adopt a system of human resource accounting. It is very important to know the perceptions of the management about the specific uses to which HRA information can be put. Because it is the management to decide regarding adoption of system of HRA and in what form it should be made available to the internal and external users. The proposed work is a step forward in that direction. 


\section{Objectives Of Study}

The objectives of the study are as under:

1. To determine the return on investment

2. To determine the human resource management

3. To determine the worth of human resource

4. To provide a sound and effective basis for asset control

5. To allow management personnel to monitor effectively the use of human resource

6. to understand the perception of the management regarding utility of Human Resource Accounting in decision making

\section{HYPOTHESIS}

In order to realize the above objectives, the following hypothesis has been formulated.

Hypothesis 1

H01: There is significant relationship among the adaptation of HRA technique and profit earning capacity (enhancing financial performance)

H11: There is negative relationship among the adaptation of HRA technique and profit earning capacity

\section{Hypothesis 2}

H01: There is significant relationship among the adaptation of HRA technique and recruitment, selection and development of employees

H11: There is negative relationship among the adaptation of HRA technique and recruitment, selection and development of employees

\section{Hypothesis 3}

H01: There is significant relationship among the adaptation of HRA technique and enhancing operational performance

H11: There is negative relationship among the adaptation of HRA technique and enhancing operational performance

\section{Hypothesis 4}

H01: There is significant impact of HRA technique on the loss due to turnover of employees.

H11: There is negative impact of HRA technique on the loss due to turnover of employees.

\section{Research Methodology}

Research methodology comprises the research design, sample design, sources of data, selection of data, various designs and techniques used for analyzing the data. The methodology used for the study at hand is as under:

Research Design: The research design used for the research problem in hand is causal research as the objective is to determine which variable might be causing certain behavior, i.e. whether there is a cause and effect relationship between variables. In order to determine cause and effect, it is important to hold the variable that is assumed to cause the change in the other variable(s), constant, and then measure the changes in the other variable(s). This type of research is very complex and the researcher can never be completely certain that there are not other factors influencing the causal relationship, especially when dealing with people's attitudes and motivations.

Independent Variables: profit, growth, recruitment, efficiency, turnover, development, acquisition, evaluating performance

Dependent Variables: Human resource valuation

Sample Design: The sample design adopted for the research problem in hand is convenience random sampling. The following points are also included in sample design for the purpose of the study:

- Sample Size: The sample size for the study was 400.

- Sampling Unit: The study includes executives, managers, investors and shareholder.

- Sample Area: The sample area for the study in hand was metro cities.

\section{METHODS OF DATA COLLECTION}

For the study in hand, both the primary and secondary data was collected. The sources of collecting both the data is as follows: 
Sources of Primary Data: The primary data for the study was collected directly from target respondents through structured questionnaire. This questionnaire includes the personal information about the respondents. The questions asked to respondents were brand of the electronic product they had purchased, selection criteria for buying a particular product.

Sources of Secondary Data: The secondary data for the study was collected from annual report of different companies of different industry.

\section{TOOLS FOR ANALYSIS OF DATA}

Along with the usual statistical tools such as tables, percentages, mean, standard deviation, rank method for correlation, Chi-square test was used for analyzing the data which helps in arriving at sound conclusions.

\section{IV. $\quad$ Research Technique Applied}

Likert Five-Point scale was applied in order to analyze the results. The percentage response for each category was calculated and the various weights assigned to different opinions as per Likert Five Point scale i.e. Strongly agree $=5$, Agree $=4$, Neutral $=3$, Disagree $=2$, Strongly disagree $=1$.The mean scores and standard deviation scores were calculated for the same. The result of the study is summarized in Table 1

Table -1

respondent as per category-wise

\begin{tabular}{|l|r|r|r|r|}
\hline user & \multicolumn{1}{|l|}{ survey done for } & \multicolumn{1}{|l|}{ respondent } & percentage & \\
\hline managers & 150 & 100 & 40 & 40 \\
\hline executives & 150 & 100 & 40 & 80 \\
\hline shareholder & 50 & 25 & 10 & 90 \\
\hline investors & 50 & 25 & 10 & 100 \\
\hline total & 400 & 250 & 100 & \\
\hline
\end{tabular}

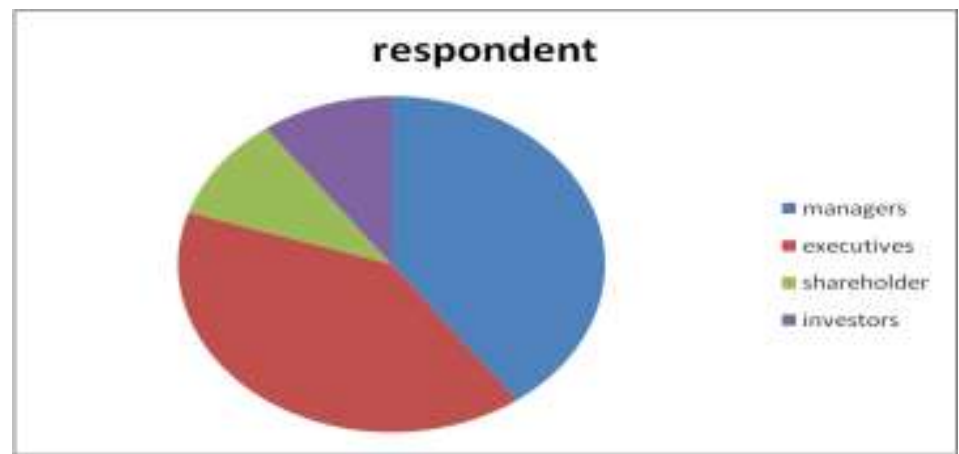

Table-2

respondent as per industry-wise

\begin{tabular}{|l|r|r|r|r|}
\hline Industry & survey done for & respondent & percentage & $\begin{array}{c}\text { Cumulative } \\
\text { percentage }\end{array}$ \\
\hline steel & 150 & 40 & 16 & 16 \\
\hline IT & 150 & 40 & 16 & 32 \\
\hline Engineering & 50 & 40 & 16 & 48 \\
\hline metal & 50 & 30 & 12 & 60 \\
\hline power & 400 & 30 & 12 & 72 \\
\hline oil \& petrol & 50 & 25 & 10 & 82 \\
\hline natural resources & 50 & 25 & 10 & 92 \\
\hline cement & 50 & 20 & 8 & 100 \\
\hline total & 400 & 250 & 100 & \\
\hline
\end{tabular}




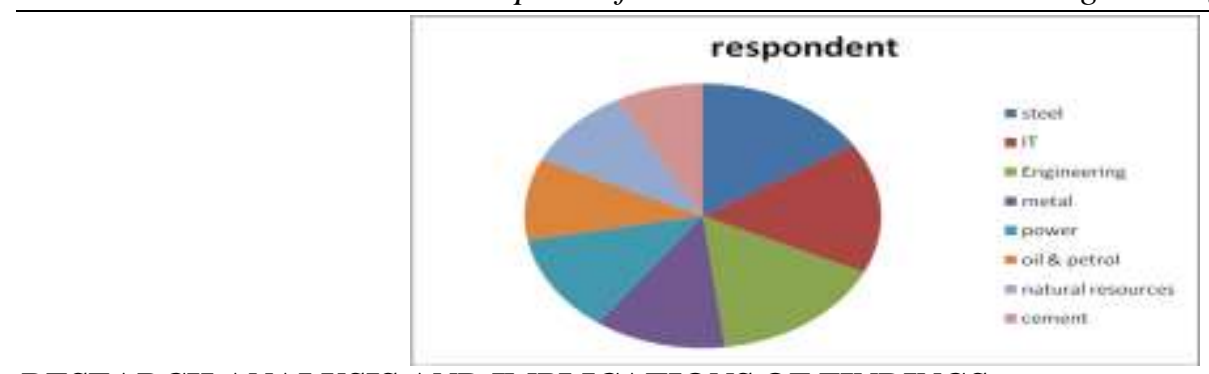

\section{RESEARCH ANALYSIS AND IMPLICATIONS OF FINDINGS}

TABLE 2: PERCEPTIONS OF EXECUTIVES RELATED TO VARIOUS ASPECTS OF MANAGERIAL USES OF HUMAN RESOURCE ACCOUNTING

\begin{tabular}{|c|c|c|c|c|c|c|c|c|c|}
\hline S.No. & Response Questions & 5 & 4 & 3 & 2 & 1 & Mean & $\begin{array}{l}\text { Standard } \\
\text { Deviation }\end{array}$ & Rank \\
\hline & & $\%$ & $\%$ & $\%$ & $\%$ & $\%$ & & & \\
\hline 1 & $\begin{array}{l}\text { Is the Human Resources Accounting in the initial stage and required } \\
\text { for focus to implementation? }\end{array}$ & 60 & 25 & 10 & 5 & 0 & 14.5 & 36 & 4 \\
\hline 2 & $\begin{array}{l}\text { Are the different concerns adopting the different method to value } \\
\text { human assets? }\end{array}$ & 40 & 35 & 15 & 10 & 0 & 17 & 33 & 2 \\
\hline 3 & $\begin{array}{l}\text { Is there lack of single universal and standard method of valuing } \\
\text { human assets in India? }\end{array}$ & 15 & 25 & 10 & 30 & 20 & 19.5 & 31 & 1 \\
\hline 4 & $\begin{array}{l}\text { Are the different concerns showing the human assets in different } \\
\text { manner in their annual report? }\end{array}$ & 15 & 35 & 5 & 40 & 5 & 17 & 33 & 2 \\
\hline 5 & $\begin{array}{l}\text { Is there so much of scope for improving the widely adopted present } \\
\text { defective system of Human Resources Accounting? }\end{array}$ & 5 & 10 & 10 & 35 & 40 & 14.5 & 33 & 4 \\
\hline 6 & $\begin{array}{l}\text { Whether HRA may prove useful for the multinational and large } \\
\text { companies but not for the small enterprises? }\end{array}$ & 20 & 50 & 10 & 10 & 10 & 14.5 & 34 & 4 \\
\hline 7 & Do HRA provide any contribution in enhancing profitability? & 15 & 70 & 10 & 5 & 0 & 12.5 & 39 & 9 \\
\hline 8 & $\begin{array}{l}\text { HRA provides measurements for budgeting human resource } \\
\text { acquisition \& development }\end{array}$ & 18 & 72 & 3 & 7 & 0 & 12.5 & 39 & 9 \\
\hline 9 & HRA helps in personnel selection process & 12 & 78 & 7 & 3 & 0 & 9.5 & 41 & \\
\hline 10 & $\begin{array}{l}\text { HRA helps in resource allocation among various HR development } \\
\text { programmes }\end{array}$ & 14 & 72 & 11 & 3 & 0 & 12.5 & 39 & 9 \\
\hline 11 & $\begin{array}{l}\text { HRA helps in providing estimate the cost of recruitment from } \\
\text { outside \& development from inside }\end{array}$ & 11 & 79 & 5 & 5 & 0 & 8 & 41 & 16 \\
\hline 12 & HRA helps management in human resources conservation & 40 & 40 & 10 & 10 & 0 & 14.5 & 34 & 4 \\
\hline 13 & HRA controls the loss due to turnover of employees & 16 & 71 & 8 & 5 & 0 & 12 & 39 & 14 \\
\hline 14 & HRA leads to alienation & 25 & 69 & 3 & 3 & 0 & 11 & 39 & 15 \\
\hline 15 & HRA helps in utilization of HR's effectively \& efficiently & 28 & 58 & 5 & 9 & 0 & 14 & 36 & 8 \\
\hline 16 & HRA helps in better reward administration & 15 & 85 & 0 & 0 & 0 & 7.5 & 44 & 17 \\
\hline 17 & HRA helps in evaluation of performance of personnel & 11 & 81 & 4 & 4 & 0 & 7.5 & 42 & 17 \\
\hline 18 & HRA creates conditions to the best treatment of personnel & 15 & 70 & 10 & 5 & 0 & 12.5 & 39 & 9 \\
\hline 19 & HRA helps in performance evaluation process & 18 & 72 & 3 & 7 & 0 & 12.5 & 39 & 9 \\
\hline
\end{tabular}

\section{EMPIRICAL ANALYSIS AND FINDING}

\section{HUMAN RESOURCES ACCOUNTING AND ITS CURRENT PRACTICES}

Human Resources accounting, also known as Human Asset Accounting, involved identifying, measuring, capturing, tracking and analyzing the potential of the human resources of a company and communicating the resultant information to the stakeholders of the company. It was a method by which a cost was assigned to every employee when recruited, and the value that the employee would generate in the future. Human Resource accounting reflected the potential of the human resources of an organization in monetary terms, in its financial statements. First six questions are asked relating to current practices in HRA. Other than question 3 and 4, have 60-75\% responses are in favour. Mean is between 14-19.

\section{HUMAN RESOURCES ACCOUNTING AND ITS IMPACT ON FINACIAL PERFORMANCE}

HRA focuses on the valuation of employee's performance, skill and values. It measures the total expenditure on recruiting; selection and development. Do HRA provide any contribution in enhancing profitability? HRA provides measurements for budgeting human resource acquisition \& development? Is it beneficial for the progress of the companies and to enhance profits? These questions show the impact of HRA on financial performance. For all the question $15-20 \%$ responded reply in strongly favour and $70-80 \%$ are agreed to it. $10 \%$ are natural and 5\% are disagree. The question scored 14.5 mean with 34.25 of standard deviation. 
Impact Of Human Resourses Accounting On Organisatinal Performance

\section{HUMAN RESOURCES ACCOUNTING AND ITS IMPACT ON COST REDUCTION}

Is it the measurement of cost and value of people as organizational resources? Whether the HRA will enhance the cost for the consumer or not? The response to fifth question in this regard was that 95 percent of the respondents agreed with this statement including 26.32 percent respondents strongly agreed and 5 percent remained neutral. The question scored 4.21 mean with 0.53 of standard deviation.

\section{HUMAN RESOURCES ACCOUNTING AND ITS IMPACT ON OPERATIONAL PERFORMANCE}

HRA helps in providing estimate the cost of recruitment from outside \& development from inside. The response to fifteen question 'HRA helps in utilization of HR's effectively \& efficiently? in this regard was that 58 percent of the respondents agreed with this statement including 28 percent respondents strongly agreed and 5 percent remained neutral. The question scored mean 14with 36 of standard deviation.

\section{HRA AND ACQUISITION OF EMPLOYEES AND TRANSFORMATION AND IMPROVEMENT IN QUALITY}

The acquisition of human resources involves recruiting, selecting and hiring people to meet the organization's present and expected workforce needs to understand the perception of managers. The development of human resources involves various forms of trainings designed to enhance people's technical, administrative and interpersonal skills. These skills in turn increase their value to an organization. Question 8 to 12 is asked to find out the impact of HRA on acquisition of HR. Does HRA favour and develop to promote Human Resources of the concerns? HRA provides measurements for budgeting human resource acquisition \& development? HRA helps in personnel selection process? HRA helps in providing estimate the cost of recruitment from outside \& development? HRA helps management in human resources conservation?

The question regarding importance of HRA for selection of HRA, Out of the respondents, 12 agreed with the statement including 78 percent of the respondents who strongly agreed. The mean score of this question was 12.5 with the standard deviation of 39 percent. None of the respondents disagreed with the statement. The second question was in relation to the help provided by human resource accounting by providing measurements of the standard costs of recruiting, selecting and hiring people that can be used to prepare human resource acquisition budgets. 18 percent of the respondents agreed, 72percent strongly agreed and 10 percent remained neutral. The mean score of this question was 12.5 and standard deviation was 39. The third question was in relation to the development of human resources was to find whether HRA helps employees to develop their skill, talent and knowledge in which HRA can play a role by providing monetary measurements of the expected value of people.

\section{HUMAN RESOURCES ACCOUNTING AND ITS IMPACT ON EVALUATION PERFORMANCE AND MOTIVATION}

Human resource evaluation is the process of measuring, evaluation and assessing the value of people to an organization. It involves measuring the performance and promotability of people. Human resources are typically evaluated by non monetary methods. For that monetary methods of human resource evaluation are needed. HRA can be useful in the evaluation process by developing reliable methods of measuring the value of people of an organization. They permit human resource management decisions to be made on a cost-value basis. The question number sixteen, Does HRA helps in better reward administration?, concerned with this aspect showed that only 85 percent of the respondents are neutral and the rest either strongly agree or agree with the statement. The question number seventeen, Does HRA helps in evaluation of performance of personnel? Concerned with this aspect showed that only 81 percent of the respondents are neutral and the rest either strongly agree or agree with the statement. HRA creates conditions to the best treatment of personnel. 18 percent of the respondents agreed, 70 percent strongly agreed and 12 percent remained neutral. The mean score of this question was 15 and standard deviation was 38. HRA helps in performance evaluation process. 18 percent of the respondents agreed, 72percent strongly agreed and 10 percent remained neutral. The mean score of this question was 12.5 and standard deviation was 39 .

\section{HUMAN RESOURCES ACCOUNTING AND ITS IMPACT ON RETENTION RATE}

The response on the question "HRA controls the loss due to turnover of employees" was positive from 87\% executives. It shows importance of HRA in retaining efficient employees. An organization's human resources may take several forms such as technical capabilities of individuals or that of an effectively functioning management team. Conservation of human resources is a process of maintaining the capabilities of people as individuals and the effectiveness of the human system developed by the organization. The conservation of human resources of an organization is typically a measurement of turnover of rates. The problem of human resource turnover has always been a matter of great concern to the personnel managers of the organization. Most employers have recognized that human resource turnover is a serious problem. They are unhappy with the high rates of personnel turnover and the consequent high costs involved in recruiting and 
training replacements. Organizations do employ various programs whereby they can minimize the employee turnover. Human resource accounting helps the management in measuring and reporting the loss to the organization as a result of turnover in quantitative terms.

\section{HUMAN RESOURCES ACCOUNTING AND ITS IMPACT ON GROWTH OF THE CONCERN}

HRA finally increase the growth of the concern. It increases economic value addition of the company. Human resource emphasis on wealth maximizes. Whether HRA is useful for all the concern in your opinion? Does HRA help in taking managerial decision? Has it a great hand in the success of an organization? 90 percent of the respondents agreed, 5 percent strongly agreed and 3 percent remained neutral. The mean score of this question was 5 and standard deviation was 30 .

From above analysis it is find out that HRA provides the beneficial information to management to take decision and to know about current practices that till what extent HRA helpful to various questions:

1. Is it beneficial in communicating information in order to facilitate effective management?

2. Is it the measurement of cost and value of people as organizational resources?

3. Is HRA equally beneficial for both external and internal user?

4. Does HRA favour and develop to promote Human Resources of the concerns?

5. Does HRA inspire towards the social responsibilities?

6. Does HRA help in taking managerial decision?

7. Whether HRA is useful for all the concern in your opinion?

8. Which method is best in your opinion to value the Human Resources?

9. Which user is the most beneficial by adopting the HRA?

TABLE 2: PERCEPTIONS OF MANAGERS RELATED TO VARIOUS ASPECTS OF MANAGERIAL USES OF HUMAN RESOURCE ACCOUNTING

\begin{tabular}{|c|c|c|c|c|c|c|c|c|c|}
\hline S.No. & Response Questions & 5 & 4 & 3 & 2 & 1 & Mean & $\begin{array}{l}\text { Standard } \\
\text { Deviation }\end{array}$ & Rank \\
\hline & & $\%$ & $\%$ & $\%$ & $\%$ & $\%$ & & & \\
\hline 1 & $\begin{array}{l}\text { Whether the HRA will enhance the cost } \\
\text { for the consumer or not? }\end{array}$ & 20 & 70 & 5 & 5 & 0 & 13 & 39 & 9 \\
\hline 2 & $\begin{array}{l}\text { Is it essential to adopt Human Resource } \\
\text { Accounting to face the acute competition } \\
\text { in the era of globalization? }\end{array}$ & 18 & 67 & 3 & 12 & 0 & 13 & 39 & 9 \\
\hline 3 & $\begin{array}{l}\text { Will the consumer also be affected by } \\
\text { showing HRA as an asset by Indian } \\
\text { company? }\end{array}$ & 10 & 78 & 9 & 3 & 0 & 10 & 41 & 16 \\
\hline 4 & Should HRA continue in future? & 16 & 70 & 11 & 3 & 0 & 13 & 39 & 9 \\
\hline 5 & $\begin{array}{l}\text { Is HRA compulsory in foreign } \\
\text { countries? }\end{array}$ & 11 & 79 & 5 & 5 & 0 & 11 & 41 & 19 \\
\hline 6 & $\begin{array}{l}\text { Is it beneficial for the progress of the } \\
\text { companies and to enhance profits? }\end{array}$ & 30 & 60 & 10 & 10 & 0 & 15 & 34 & 4 \\
\hline 7 & $\begin{array}{l}\text { Should it be made necessary for all } \\
\text { public and private companies? }\end{array}$ & 12 & 75 & 8 & 5 & 0 & 12 & 39 & 14 \\
\hline 8 & $\begin{array}{l}\text { Is Human Resource the most important } \\
\text { assets of the concern? }\end{array}$ & 27 & 67 & 3 & 3 & 0 & 15 & 39 & 15 \\
\hline 9 & $\begin{array}{l}\text { Has it a great hand in the success of an } \\
\text { organization? }\end{array}$ & 25 & 59 & 7 & 9 & 0 & 14 & 36 & 8 \\
\hline 10 & $\begin{array}{l}\text { Is it beneficial in communicating } \\
\text { information in order to facilitate } \\
\text { effective management? }\end{array}$ & 15 & 85 & 0 & 0 & 0 & 15 & 44 & 17 \\
\hline 11 & $\begin{array}{l}\text { Is it the measurement of cost and value } \\
\text { of people as organizational resources? }\end{array}$ & 11 & 81 & 4 & 4 & 0 & 11 & 42 & 17 \\
\hline 12 & $\begin{array}{l}\text { Is HRA equally beneficial for both } \\
\text { external and internal user? }\end{array}$ & 15 & 70 & 10 & 5 & 0 & 13 & 39 & 9 \\
\hline 13 & $\begin{array}{l}\text { Does HRA favour and develop to } \\
\text { promote Human Resources of the } \\
\text { concerns? }\end{array}$ & 18 & 72 & 3 & 7 & 0 & 13 & 39 & 9 \\
\hline 14 & $\begin{array}{l}\text { Does HRA inspire towards the social } \\
\text { responsibilities? }\end{array}$ & 60 & 25 & 10 & 5 & 0 & 15 & 36 & 4 \\
\hline 15 & $\begin{array}{l}\text { Does HRA help in taking managerial } \\
\text { decision? }\end{array}$ & 40 & 35 & 15 & 10 & 0 & 17 & 33 & 2 \\
\hline 16 & $\begin{array}{l}\text { Whether HRA is useful for all the } \\
\text { concern in your opinion? }\end{array}$ & 5 & 90 & 2 & 3 & 0 & 5 & 31 & 1 \\
\hline 17 & $\begin{array}{l}\text { HRA is best system to value the Human } \\
\text { Resources in your opinion? }\end{array}$ & 15 & 40 & 5 & 40 & 0 & 17 & 33 & 2 \\
\hline 18 & $\begin{array}{l}\text { HRA is the most beneficial for all the } \\
\text { user? }\end{array}$ & 5 & 70 & 10 & 15 & 0 & 15 & 33 & 4 \\
\hline
\end{tabular}

Most favorable result are in favour of the question "Whether HRA is useful for all the concern in your opinion" around $95 \%$ respondent are in favour, mean is 5 and standard deviation is 31 . Does HRA help in taking 
managerial decision? Like the same the following two questions are at second rank and mostly favoured by respondent. Does HRA help in taking managerial decision? HRA is best system to value the Human Resources in your opinion?

Human resource accounting provides quantitative information about the value of human asset, which helps the top management to take decisions regarding the adequacy of human resources. Hence, It is Concluded that, the Human Resources are an indispensable but often neglected element is thus to be fore grounded into the industrial area for the betterment of the economy. Human Resource accounting reflected the potential of the human resources of an organization in monetary terms, in its financial statements.

\section{Conclusion}

On the basis of the empirical analysis through the statistical tools like mean and standard deviation the various aspects of managerial uses of human resource accounting, is tried to find out. The usefulness of the human resource accounting can be concluded in providing the estimates and measuring the cost occered on acquiring, promoting, training, development. HRA is equally beneficial for employees and management. Managerial decision can be taken on the behalf of statement of HRA. By analyzing the statement, productivity if employees can be measure and can motivate to attain their goals and enhancing their work efficiency. On the other hand employees got a psychological satisfaction to be assumed them as important assets and involving them into decision making process, call for suggestion, participating in voting right and right in ownership.

Finally we can say that the output of HRA system can be used to enhance performance of employees as well as company and to take a variety of decisions in the area of human resource management. But the number of organizations that have adopted HRA system in India is low as it is not compulsory for the Indian organizations to value human resources and mostly used by public sector but private sectors companies are least interesting. Still all those companies who are adopting this accounting system are enjoying their strong financial performance and efficient management.

\section{References}

[1] Bayes, Paul Eugene. (1984): An Empirical Investigation of the Effects of Human Resource Accounting Information on DecisionMaking: Results of Mail Survey, Thesis, University of Kentucky, U.S.A.

[2] Brummet, R.L., Flamholtz, E.G., Pyle, W.C. (1969), "Human Resource Accounting: A Tool to Increase Managerial Effectiveness", Management Accounting, p.p.12-15.

[3] Flamholtz, Eric. G. (1971), "Should Your Organization Attempt to Value its Human resources?" California Management Review, Winter, pp. 40-45.

[4] Flamholtz, Eric. G. (1979), "Human Resource Accounting: State of the Art and Future Prospects", Annual Accounting Review, Vol. 1, p. 219.

[5] Framholtz, Eric. G. (1999), "Human Resource Accounting: Advances in Concepts, Methods \& Applications", Kluwer Academic Publishers, Third Edition, p.12.

[6] Gul, Ferdinand A. (1984), "An Empirical Study of the Usefulness of Human Resources Turnover Cost in Australian Accounting Firm", Accounting,

[7] Organization and Society, Vol. 9, pp. 233-239.

[8] Gupta, D.K. (1990), "Human Resource Accounting In India: A Perspective", ASCI Journal of Management, Vol.20, No.3, September, pp-1-9.

[9] Gupta, D.K. (1992), "Probable Problem Areas Confronting Human Resource Accounting: A Survey" Journal of Accounting and Finance, Vol. VI, No. 1, spring, pp71-78.

[10] Levine, Marc. (1980),"Perspective in Accounting for Human Resources”, The Chartered Accountant, October, pp. 295-97.

[11] Malik, R.K. (1993), "Human Resource Accounting and Decision-Making", Anmol Publishers, New Delhi.

[12] Sen, D.K., Jain, S.C., Jat, S.L and Saha, R.K. (2008), "Human Resource Accounting Information: It's Impact on Internal Decision-Making", The Journal of Accounting and Finance, Vol. XXII, No. 1, Oct-March, pp. 23-56.

[13] Tomassini, Lawrence A. (1977), "Assessing the Impact of Human Resource Accounting: An Experimental Study of Managerial Decision Preferences", The Accounting Review, Vol. 52, No. 4, October, pp. 904-914. 